\title{
REVISÃO
}

\section{THE ROLE OF MINERAL NUTRITION ON YIELDS AND FRUIT QUALITY IN GRAPEVINE, PEAR AND APPLE ${ }^{1}$}

\author{
GUSTAVO BRUNETTO², GEORGE WELLINGTON BASTOS DE MELO ${ }^{3}$, \\ MORENO TOSELLI ${ }^{4}$, MAURIZIO QUARTIERI $^{5}$, MASSIMO TAGLIAVINI $^{6}$
}

\begin{abstract}
Fertilization of temperate fruit trees, such as grapevine (Vitis spp.), apple (Malus domestica), and pear (Pyrus communis) is an important tool to achive maximum yield and fruit quality. Fertilizers are provided when soil fertility does not allow trees to express their genetic potential, and time and rate of application should be scheduled to promote fruit quality. Grapevine berries, must and wine quality are affected principally by $\mathrm{N}$, that regulate the synthesis of some important compounds, such as anthocyanins, which are responsible for coloring of the must and the wine. Fermenation of the must may stop in grapes with low concentration of $\mathrm{N}$ because $\mathrm{N}$ is requested in high amount by yeasts. An $\mathrm{N}$ excess may increase the pulp to peel ratio, diluting the concentration of anthocyanins and promoting the migration of anthocyanins from berries to the growing plant organs; a decrease of grape juice soluble solid concentration is also expected because of an increase in vegetative growth. Potassium is also important for wine quality contributing to adequate berry maturation, concentration of sugars, synthesis of phenols and the regulation of $\mathrm{pH}$ and acidity. In apple and pear, $\mathrm{Ca}$ and $\mathrm{K}$ are important for fruit quality and storage. Potassium is the most important component of fruit, however, any excess should be avoided and an adequate $\mathrm{K}$ :Ca balance should be achieved. Adequate concentration of $\mathrm{Ca}$ in the fruit prevents pre- and post-harvest fruit disorders and, at the same time, increases tolerance to pathogens. Although $\mathrm{N}$ promotes adequate growth soil $\mathrm{N}$ availability should be monitored to avoid excessive $\mathrm{N}$ uptake that may decrease fruit skin color and storability.
\end{abstract}

Index terms: Macronutrients, micronutrients, nutritional status, production, quality.

\section{NUTRIÇÃO MINERAL, PRODUTIVIDADE E COMPOSIÇÃO DE FRUTOS DE FRUTÍFERAS DE CLIMA TEMPERADO: VIDEIRA, PEREIRA E MACIEIRA}

\begin{abstract}
RESUMO - A adubação em frutíferas de clima temperado, entre as quais, videira (Vitis spp.), macieira (Malus domestica) e pereira (Pyrus communis), é realiza quando o solo não possui a capacidade de fornecer a quantidade de nutrientes de que a planta necessitaria, possibilitando às plantas expressarem seu potencial genético. Mas a aplicação de nutrientes na adubação de pré-plantio, crescimento e, especialmente, manutenção pode afetar o estado nutricional das frutíferas, refletindo-se na produtividade e na qualidade dos frutos. Porém, estas informações são dispersas na literatura e, por isso, a presente revisão, sem a pretensão de esgotar o assunto, objetivou compilar e apresentar informações sobre os efeitos de nutrientes na produtividade e na composição de frutos de videira, pereira e macieira. Ao longo do texto, são apresentadas informações sobre o impacto do fornecimento de nutrientes sobre o estado nutricional, a produtividade e as variáveis de qualidade dos frutos, como a cor, tamanho, teor de nutrientes, sólidos solúveis totais (SST), acidez, pH, antocianinas, polifenóis e desordens fisiológicas, que podem afetar não só a aquisição dos futos pelo consumidor, mas também os produtos elaborados a partir dos frutos, como, por exemplo, os sucos, vinhos, etc..., bem como vida pós-colheita e de prateleira de alguns frutos, os quais a maçã e a pera.
\end{abstract}

Termos para indexação: Macronutrientes, micronutrientes, estado nutricional, produção, qualidade.

\footnotetext{
'(Trabalho 103-15). Received on: 16-04-2015. Accepted for publication on 08-06-2015.

${ }^{2}$ Agronomist, Doctor in Soil Science, Prof. of Soil Science and Plant Nutrition, Departament of Soil Science and Graduate Studies Program in Soil Science (UFSM), Santa Maria-RS, Brazil. Fellowship Holder in Research Productivity from the CNPq, E-mail: brunetto.gustavo@gmail.com

${ }^{3}$ Agronomist, Doctor in Soil Science, Researcher of the Embrapa Uva e Vinho, Bento Gonçalves-RS, Brazil, E-mail: wellington. melo@embrapa.br

${ }^{4}$ Agronomist, Doctor in Horticulture, Department of Agricultural Sciences, University of Bologna, viale Fanin, 46, 40127, Bologna Italy, E-mail: maurizio.quartieri@unibo.it

${ }^{5}$ Agronomist, Prof. of Department of Agricultural Sciences, University of Bologna, viale Fanin, 46, 40127, Bologna Italy. E-mail: moreno.toselli@unibo.it

${ }^{6}$ Agronomist, Prof. of Horticulture and Tree ecosystems, Faculty of Science and Technology, Free University of Bozen-Bolzano, 39100 Italy. e-mail: massimo.tagliavini@unibz.it
} 


\section{INTRODUCTION}

Temperate fruit trees, such as the grapevine (Vitis spp.), apple (Malus domestica Borkh.), and pear tree (Pyrus communis L.) should be fertilized whenever the soil cannot provide a sufficient amount of nutrients to feed the plant for maximum yield. However it appears that this simple concept is not yet fully understood. In general, in the most traditional fruit production regions, fertilization programs are based on soil fertility, tree requirements and crop nutritional status. The results of soil and tissue analyses are compared with critical nutrient ranges according to the probability that plants respond to additions of nutrients. Some systems also consider other recommendation criteria, such as expected yield, plant growth, which may be estimated by the length of new shoots, and fruit analysis, as is the case of trees (CQFS-RS/SC, 2004). Not all fertilizer recommendation guidelines for temperate fruit crops are based on results of long term regional studies. Some recommendations for fruit trees, such as those established in the first versions published in the Fertilization and Liming Manual for the States of Rio Grande do Sul and Santa Catarina (2014), lack of results collected regionally (CQFS-RS/SC, 2004).

Fertilization is considered one of the most effective tool to increase the profits in fruit tree cropping; the relatively low cost of fertilizers and the positive response of tree vegetative and reproductive organs to added nutrients triggered a general use of fertilizer with low attention to actual tree requirements. However, in view of the increasing global market, it is now strategic to improve fruit quality offering a product that meets customer demand in terms of organoleptic characteristics, functional properties and environment.

Excessive nutrient availability compared to plant requirements convey negative results such as excessive plant vigor, decreased yield and fruit skin color, abortion of flowers (MARTÍN et al., 2004; HUBER; JONES, 2013; MARTÍN et al., 2004), as well as increased incidence of fungal diseases on leaves and fruit (HUBER; THOMPSON, 2007). Often, an increase in fruit yield is not observed because soil nutiernt availability is already within the adequate range (MENGEL; KIRKBY, 2001); above upper threshold, toxicity symptoms are expected. Sometimes even when a soil nutrient availability is lower than lower threshold, trees do not respond to fertilization because the nutrient reserves build up in perennial organs in previous years (BRUNETTO et

\section{al., 2014a).}

The practice of fertilization may affect fruit quality from morphological, physical, chemical, and organoleptic points of view. In particular, fruit quality with reference to chemical composition may be estimated through macro- and micronutrients, $\mathrm{pH}$, total soluble solids (TSS), total or titratable acidity, organic acids, anthocyanins, total polyphenols, vitamins, etc. (SMART, 1991; CHADHA; SHIKHAMANY, 1999). The quality of fruit must meet the standards for fresh market, storage or fruit processing. Consequentely fertilization management should be adjusted to the final destination.

The aim of this review is to provide information regarding the effects of the application of nutrients on yields and fruit chemical composition of three temperate climate species, namely grape, pear and apple.

\section{GRAPEVINE}

\section{Nitrogen}

The application of nitrogen $(\mathrm{N})$ on grapevines should be undertaken with caution because of its conflicting effects on vegetative growth, yield, and chemical composition of the grapes, must and wine (BELL; HENSCHKE, 2005; BRUNETTO et al., 2007). High rates of nitrogen fertilizers as $\mathrm{NO}_{3}{ }^{-} \mathrm{N}$ and $\mathrm{NH}_{4}^{+}-\mathrm{N}$, may stimulate vegetative growth hence reducing solar radiation within the plant canopy, favoring the incidence of fungal diseases on the leaves and fruits, reducing the number of pollinated flowers, producing a lower number of berries per bunch and, in the end, delaying leaf senescence and plant dormancy (KELLER et al., 1999; DUCHÊNE et al., 2001; BRUNETTO et al., 2007, 2009; 2012b). In addition, the excessive vigor of grapevines and the lack of light within the canopy may reduct the activity of enzymes that regulate the synthesis of some important compounds, such as anthocyanins (red-colored phenolic compounds) which color the must and the wine. An increase of the pulp to peel ratio dilutes the concentration of anthocyanins and stimulates the migration of anthocyanins located in berries to growing plant organs, including the new shoots (KELLER; HRAZDINA, 1998; KELLER et al., 1999; TESIC et al., 2007; BRUNETTO et al., 2009). As a result, the yield and composition of the grape, must and wine could be affected.

The effect of $\mathrm{N}$ on grape yield depends mostly on soil physico-chemical characteristics. In sandy soils with low organic matter content, a yield increase is normally expected in grape after the addition of $\mathrm{N}$ fertilisers (GOLDSPINK; GORDON, 
1991; BELL; ROBSON, 1999), although exceptions are also possible, considering the low $\mathrm{N}$ requirement of grape, $\mathrm{N}$ accumulated reserves in the plant and organic N mineralization (BRUNETTO et al., 2011, 2014a). For example in an experiment carried out in the region of Campanha in Rio Grande do Sul, South Brazil, applications of $0,15,30,45,60$, and $85 \mathrm{~kg} \mathrm{~N}$ ha $^{-1}$ as urea (BRUNETTO et al., 2007) and compost (BRUNETTO et al., 2013) in an Hapludalf soil did not influence the yield and quality of the 'Cabernet Sauvignon' grapevine. The lack of response of grape to added $\mathrm{N}$ was expected expecially in clay or clay loam soils with medium to high organic matter content, that generally provides sufficient amounts of mineral N though mineralization (DELAS et al., 1991; DAL BÓ, 1992).

Nitrogen fertilization influences the different aspects of grape quality from cluster morphology (length, width and weight of bunches to number of berries per bunch, weight of the berries, etc.), juice chemical composition ( $\mathrm{pH}$, TSS, total titratable acid, organic acids, anthocyanin, and total polyphenols), and organoleptic properties (CHADHA; SHIKHAMANY, 1999). For example, tartaric and malic acid represent more than $90 \%$ of all the acids in the berry and indicate the stability and longevity of the wine. The anthocyanins are found in larger quantity in the peel and determine the color of the grape, the juice, and the wine. Total polyphenols, also found in greater amounts in the peel, normally increase as response to $\mathrm{N}$ fertilization and contribute to color intensity, tonality, and taste characteristics of grape and wine (CHADHA; SHIKHAMANY, 1999).

In the central region of Washington State, USA, the $\mathrm{pH}$, total $\mathrm{N}$, and ammoniacal $\mathrm{N}$ in grape and must increased linearly with rates of $\mathrm{N}(0,56$, 112, and $224 \mathrm{~kg} \mathrm{~N} \mathrm{ha}^{-1}$ ) (SPAYD et al., 1994), but showed effect on $\mathrm{K}$ concentration, TSS, and malic and tartaric acids in the must. Other reports (SPAYD et al., 1995), showed a negative effect of $0,30,60$, and $90 \mathrm{~kg} \mathrm{~N} \mathrm{ha-1} \mathrm{on} \mathrm{TSS.} \mathrm{In} \mathrm{California,} \mathrm{rates} \mathrm{of} 56$ and $112 \mathrm{~kg} \mathrm{~N}^{-1}$ reduced TSS in the grape and the must (CHISTENSEN et al., 1994). In Portugal, tartaric and malic acid, and total acidity responded positively to added $\mathrm{N}\left(0,30,60\right.$, and $\left.90 \mathrm{~kg} \mathrm{~N} \mathrm{ha}^{-1}\right)$ (PACHECO et al., 1997). In largest grapevines and wine producing region in Brazil, 'Cabernet Sauvigon' showed a decrease in the anthocyanin concentration in the must (BRUNETTO et al., 2007; 2009), with increasing rates of soil applied $\mathrm{N}$ in the form of urea. In the same area of Southern Brazil, the addition of organic compost as $\mathrm{N}$ source, did not affect $\mathrm{pH}$, TSS, total titratable acidity, and tartaric and malic acids in the grape (MELO et al., 2012). The highly variable effects of added $\mathrm{N}$ reported in literature may be due to the contrasting soils and organic matter contents. Thus, discussion of the results is normally restricted to the amount of $\mathrm{N}$ applied and its impact on the yield and composition of the grape and must.

Application of $\mathrm{N}$ increased concentration of total $\mathrm{N}$, ammoniacal $\mathrm{N}$, and biotin in the must (OUGH et al., 1968), especially on 'Merlot' (BERTRAND et al., 1991) grown in a sandy soil grafted on different rootstocks. Fermenation of the must may stop in when using grapes with low concentration of $\mathrm{N}$ forms because, after $\mathrm{C}, \mathrm{N}$ is used in greatest amount by yeasts and bacteria. Thus, the concentration of $\mathrm{N}$ in the must has an impact on microbial biomass, the rate and time of fermentation, and the final products of the microbial metabolism (CANTARELLI, 1957; BISSON, 1991) such as alcohols and aroma-producing compounds in wine (RAPP; VERSINI, 1991).

\section{Potassium}

Potassium $(\mathrm{K})$ is one of the macronutrients most required by grapevines and a large amount is exported through havest. Potassium availability to grape may be assessed by leaf analysis at full bloom and at berry veraison. However, it is not always possible to determine $\mathrm{K}$ accurately in the leaves, because most $\mathrm{K}$ is present free that can be redistributed rapidly to growing organs (i. e. berries), or stored in reserve organs such as branches and roots (TAGLIAVINI; SCANDELLARI, 2013).

Leaf $\mathrm{K}$ is not always related to yield (BOOTERM et al., 2010) because plants, in general, take up an amount of $\mathrm{K}$ greater than their metabolic needs, and accumulated it into cell organelles in luxury consumption (KAMINSKI et al., 2007). However, few studies reported an increase in the number and weight of bunches, where was combined with $\mathrm{N}$ or when the $\mathrm{K}$ fertilizations was applied to soil with a $\mathrm{K}$ availability below the critical level for sufficiency (BRUNETTO et al., 2012b).

As much as $50 \%$ of total $\mathrm{K}$ taken up by the grapevines accumulates in berries. Its functions in the fruit are related to synthesis reactions and enzymatic activation, directly contributing to fruit maturation, sugar synthesis, and the maintenance of cell turgor. In addition, through its mobility in the phloem and xylem, $\mathrm{K}$ is important in the transport of solutes, the partition of assimilates, and the synthesis of polyphenols responsible for fruit color and aroma. Nevertheless, an excess of $\mathrm{K}$ may be undesirable in terms of adequate $\mathrm{pH}$ and total titratable acidity in the must (KODUR, 2011). The $\mathrm{pH}$ indicates the ionization capacity of the must and normally 
should remain below 3.5, while total titratable acidity represents the amount of free acids. Both are related to the quality (organoleptic and visual characteristics) and stability of the must and wine (oxidation capacity) (MPELASOKA et al., 2003; WALKER; BLACKMORE, 2012). Under conditions of high $\mathrm{K}$ concentration, for example, there may be a stoichiometric exchange of the protons of tartaric acid and $\mathrm{K}$, leading $\mathrm{K}$ bitartrate, a salt that precipitates and decrease organoleptic quality of the wine. This leads to a reduced transport of malic acid to the cytoplasm, a decrease of its degradation rate (MPLEASOKA et al., 2003). As a result tartaric:malic acid ratio decreases, resulting in the increase of $\mathrm{pH}$, and wine susceptibility to oxidation and microbiological damages,

\section{Phosphorus}

Phosphorus $(\mathrm{P})$ is needed for the formation of cell membranes, carbohydrate metabolism, protein synthesis, photosynthesis, respiration sugar metabolism, energy storage and transfer (FREGONI, 1980). In addition, $\mathrm{P}$ may confer special characteristics to the wines produced in a given region. For example, Zalamena et al. (2013ab) observed that cover plants increased the $\mathrm{P}$ concentration in leaves and the $\mathrm{P}$ the concentration of anthocyanins in wine. In contrast, $P$ concentration considered adequate for wine-making promotes the fermentation of the must, hence the organoleptic quality of the wine in terms of aroma and flavor (POMMER, 2003).

In geral, the $\mathrm{P}$ demand and the amount exported through harvesting is small. In addition, the mutualistic symbiosis between plant roots and endomycorrhizal fungi may facilitate $\mathrm{P}$ acquisition and limit the need for P fertilization (SIQUEIRA; MOREIRA, 2001). In Brazil, soils have a low content of available P. For that reason, when soil analysis shows $\mathrm{P}$ deficiency, phosphate fertilizers are applied at pre-planting and throughout the production cycle. If soil $\mathrm{P}$ is not sufficient to meet plant requirements, grapevines may show symptoms of $\mathrm{P}$ deficiency such as low vigor, yellowing or reddening of the basal leaves and early leaf drop. When $\mathrm{P}$ added blindly, $\mathrm{P}$ accumulation may occur, in the soil and the proportions of $\mathrm{P}$ forms change in the soil. As available $P$ forms accumulate in the soil, the $P$ could be transferred through surface runoff or underground flow (SCHMITT et al., 2014). Furthermore, high $\mathrm{P}$ contents in the soil may reduce the availability of $\mathrm{Zn}$, because of the formation of $\mathrm{Zn}$ phosphate; consequently, symptoms of Zn deficiency may be observed in grape leaves (SKINNER; MATTHEWS,
1989).

\section{Calcium, magnesium and some micronutrients}

In the acid soils of Southern Brazil, limestone is often applied before grape planting with the aim to increase soil $\mathrm{Ca}$ and $\mathrm{Mg}$ contents and to reduce Al toxicity. Liming increases base saturation of the cation exchange capacity at the expense of $\mathrm{Al}$ saturation. An increase of $\mathrm{Ca}$ tissue concentration is expected after soil application of lime leading to the activation of phosphatase and peptidase and increase rigidity of the cell walls of fruit and other grape organs (LECOURIEUX et al., 2006). An increase in $\mathrm{Mg}$ contents is also expected to improve chlorophyll synthesis (POMMER, 2003). Some studies reported that in soils with high levels of exchangeable $\mathrm{K}$, symptoms of $\mathrm{Mg}$ deficiency in grape leaves and even desiccation of the rachis may occur resulting in physiological disturbance and yield decrease (HALL et al., 2011).

In the uppermost soil layers of the most important areas for grapevine industry worldwide, an accumulation of $\mathrm{Cu}$ and $\mathrm{Zn}$ arises from the application of fungicides and the addition of organic residues as a source of $\mathrm{N}, \mathrm{P}$ and $\mathrm{K}$, (BRUNETTO et al., 2014b). The accumulation of $\mathrm{Cu}$ and $\mathrm{Zn}$ in the soil modifies the distribution of the forms of those elements, increasing the most labile forms that possibly contaminat surface and ground waters, especially in soils with a sandy texture and with low organic matter content (CASALI et al., 2008). Excessive accumulation in the soil is toxic to many crop species (GIROTTO et al., 2014). In addition, an excess of $\mathrm{Cu}$ and $\mathrm{Zn}$ may be toxic to young growing grapevines and cause physiological and biochemical stress to grapes (MIOTTO et al., 2013). This may impair the production and the chemical composition of the grape and, consequently, of the must and the wine. However, the actual negative impact of excessive $\mathrm{Cu}$ and $\mathrm{Zn}$ on yield and grape composition should be evaluated in relation to soil properties.

\section{PEAR}

\section{Nitrogen}

Optimal concentration of $\mathrm{N}$ in fruits allows a proper development of skin color, fruit size and flavor (Table 1). Fruit $\mathrm{N}$ concentration depends on grafting combination (cultivar and rootstock), environment and orchard management (Table 2), with reported value of $2.5 \mathrm{~g} \mathrm{~N} \mathrm{~kg}$ fruit $\mathrm{dw}^{-1}$ for 'Abbè Fetel' in Italy (QUARTIERI et al., 2002) to $4.5 \mathrm{~g} \mathrm{~N} \mathrm{~kg}$ fruit $\mathrm{dw}^{-1}$ for 'Conference' in Belgium

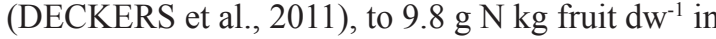


'Bartlett' grown in Argentina (SANCHEZ, 2002). Fruit $\mathrm{N}$ concentration is higher during the first stage of fruit development (cytochinesis) and decreases thereafter during fruit growth until harvest (Table 2). An excessive soil $\mathrm{N}$ availability in the summer may delay fruit maturation, have a negative impact on TSS, and decrease plant tolerance to pests and diseases as psylla (Cacopsylla pyri L.) symptoms on 'D'Anjou' (RAESE; STAIFF, 1989) and 'Bartlett' (DAUGHERTY et al., 2007), fire blight (Erwinia amylovora) (VAN DER ZWET; KEIL, 1979) and post harvest blue mold (Penicillum expansum) on 'Conference' (SUGAR et al., 1992).

Optimum $\mathrm{N}$ availability at the end of winter dormancy allows a prompt leaf development that provides assimilates for new fruit and shoot growth. Early $\mathrm{N}$ deficency may reduce leaf area, with the ensuing negative effect on fruit yield and quality. If $\mathrm{N}$ deficiency persists during the season, fruits may remain small in size and return poor flavor (Table 1).

As already reported for apple (MILLARD, 1995; TOSELLI, 2000), and pear (TAGLIAVINI et al., 1997), spring growth relies on $\mathrm{N}$ stored in permanent organ such as roots, trunk, branches and twigs during the previous year. As a result, if the $\mathrm{N}$ supply has been adequate in the previous season, $\mathrm{N}$ application can be postponed after floral petal drop. As in the case of apple, $\mathrm{N}$ applied late in the season, immediately before harvest, is not partitioned to the fruits but is stored then remobilized in the following spring during flower development (SUGAR et al., 1992). Under the climatic conditions of the Po valley in Italy, 39\% of pear fruit $\mathrm{N}$ at harvest, comes from previous year storage, $50 \%$ is taken up between March and May (first 2 months after bloom), and only $11 \%$ of $\mathrm{N}$ is from soil-uptaken from end of June to harvest, during the last 2 months of fruit growth (QUARTIERI et al., 2002). Consequentely pre harvest (4-5 weeks before harvest) $\mathrm{N}$ applications do not increase the $\mathrm{N}$ :Ca ratio and pear susceptibility to pre- and post- harvest decay (SUGAR et al.,1992; TOSELLI et al., 1998).

\section{Potassium}

Potassium $(\mathrm{K})$ is the most aboundant nutrient in the fruit where it affects positively the size, firmness, skin color, TSS, acidity, juiciness and aroma. This nutrient is also important during storage since an imbalanced $\mathrm{K}$ :Ca ratio may promote cork spot in 'D'Anjou' (CURTIS et al., 1990) and 'Alexander Lucas' (TOMALA; TRZAK, 1994). Because pear trees generally show higher absorption and transport of $\mathrm{Ca}$ to the fruit than apple (MARCELLE, 1995), the negative effect of $\mathrm{K}$ on quality of stored pear fruits is less frequent than in apple fruits. Potassium concentration in fruits is stable during the growing season ranging between 0.8 to $1.0 \%$, and it is $30-40 \%$ higher in the peel than to the pulp. As observed for $\mathrm{N}: \mathrm{Ca}$, the $\mathrm{K}:$ Ca ratio is also higher in the flesh (often $>30)$ than the peel $(<10)$. Because $\mathrm{K}$ is antagonist to both $\mathrm{Ca}$ and $\mathrm{Mg}$, if $\mathrm{K}$ increases in the soil over the normal range, both $\mathrm{Ca}$ and $\mathrm{Mg}$ uptake may decrease, as reported in 'Abbè Fetel' in Northern Italy.

\section{Phosphorus and magnesium}

Due to little plant requirement, deficiency is unlikely to occur. Phosphorous concentration decreases toward the interior of the fruit (FAUST et al., 1967); in the pear fruit, the optimum $P$ concentration range lies between 700 and $1000 \mathrm{mg}$ $\mathrm{P}\left(\mathrm{kg} \mathrm{dw}^{-1}\right)$.

Magnesium uptake can be strongly depressed by K ${ }^{+}, \mathrm{NH}_{4}^{+}, \mathrm{Ca}^{2+}$ (MARSCHNER, 1995). Deficiencies in plant tissues are common in acid soils, particularly where the soil is high in plant-available $\mathrm{K}$. In pear fruits, $\mathrm{Mg}$ ranges between 350 and 1000 $\mathrm{mg} \mathrm{kg} \mathrm{dw}{ }^{-1}$ depending on fruit stage (Table 2). The $\mathrm{Mg}$ accumulates linearly at a slow rate throughout the growing season (TAGLIAVINI et al., 2000).

\section{Calcium}

Calcium differs from other nutrients because it is transferred to fleshy fruit in amounts much smaller than leaves (SAURE, 2005). Despite Ca sufficiency in most orchard soils, localized Cadeficiency-related disorders such as bitter pit in apple and pear fruit may become a serious problem.

The dynamics and factors affecting $\mathrm{Ca}$ transfer to the fruit are still not fully understood (SAURE, 2005). Some authors reported that $\mathrm{Ca}$ uptake by the fruit occurs only during the first part of fruit growth (FAUST, 1989) or linearly until harvest (ZAVALLONI et al., 2001). Regardless the dynamics of fruit $\mathrm{Ca}$-accumulation, $\mathrm{Ca}$ has a low vascular mobility. Consequentely, its uptake and partitioning to the fruits is most consistent in the first stage of fruit development. For this reason it is essential to promote Ca uptake early in the season, approximately within the first 40-50 days after blooming (SHEAR; FAUST, 1971; SCHLEGEL; SCHOENHERR, 2002).

Calcium is involved in cell physiology, the integrity and stability of cell membranes, organization of the cell wall, and tolerance against fungal and bacterial infections (BATEMAN; LUMSDEN, 1965), because $\mathrm{Ca}$ is associatedto polygalacturonic acid as exchangeable Ca pectate (MARSCHNER, 1995). The Ca pectate is considered to be the Ca fraction best associated with fruit suitability for 
storage. The Ca pectate was found to range between $25 \%$ in untreated trees to $30 \%$ in soil fertilized In fruits of 'Abbè Fetel' the Ca pectate (TOSELLI et al., 2012). On the other hand, high Ca concentration inhibits the activity of polygalacturonase and delays ripening of fruits (MARSCHNER, 1995).

Optimum fruit $\mathrm{Ca}$ concentration promotes fruit firmness, increases disease tolerance and reduces storage related disorders. Fruit $\mathrm{Ca}$ accumulation is higher at the beginning of fruit development (during fruit cytochinesis), reaches 1800-2000 mg Ca kg dw ${ }^{1}$, and decreases thereafter throughout the season until harvest, ranging from 200 to $1000 \mathrm{mg} \mathrm{Ca} \mathrm{kg} \mathrm{dw}^{-1}$ with average values of 300-400 $\mathrm{mg} \mathrm{Ca} \mathrm{kg} \mathrm{dw}^{-1}$ (Table 2).

Many physiological disorders and susceptibility to pre- and post-harvest fungal decay are related to the Ca status of pear fruits. In 'Doyenne du Comice', a negative correlation was found between $\mathrm{Ca}$ fruit content and fruit susceptibility to superficial scald (MARCELLE, 1995). It has been reported that storage disorders such as internal breakdown of 'Passacrassane', senescent breakdown of 'Abbè Fetel' and 'Bosc' (GORINI, 1988), corkspot of 'D'Anjou' (CURTIS et al., 1990) and 'Alexander Lucas' (TOMALA; TRZAK, 1994).pre-and postharvest diseases such as brown spot (Stemphylium vesicarium), particularly frequent in 'Abbé Fetel' and 'Conference' can be reduced through increased fruit Ca concentration up to a threshold of $1000 \mathrm{mg} \mathrm{Ca}$ $\mathrm{kg}^{-1}$ (TOSELLI et al., 2012). Side rot (Phialophora malorum) in 'Bosc' was reduce applying three mid-summer sprays of 3.6 and $6 \mathrm{~g} \mathrm{Ca} \mathrm{L}^{-1}$ as $\mathrm{CaCl}_{2}$ (SUGAR et al., 1992). Considering the low mobility of $\mathrm{Ca}$ and the little permeability of the fruit cuticle during most phenological stages, foliar and soil applications of $\mathrm{Ca}$ fertilizers often show a low effectiveness in promoting $\mathrm{Ca}$ accumulation in fruit in both controlled and field studies on calcareous soils in Northern Italy (TOSELLI et al., 2012). Under such environmental conditions, largest effects were obtained with early (bloom) soil applications. Foliar $\mathrm{Ca}$ applications have been reported to be effective in sandy, low in organic matter, soils of the US Pacific Northwest (SUGAR et al., 1992), as well as in silt loam soils of Poland (GASTOL; DOMAGALASWIATKIEWICZ, 2009). Foliar applications of Ca promoted $\mathrm{Ca}$ accumulation in fruit of 'Conference' from 93 to $125 \mathrm{mg} \mathrm{kg}^{-1} \mathrm{fw}$ (fresh weight basis) in 2004 and from 76 to $101 \mathrm{mg} \mathrm{kg}^{-1}$ fw in 2005 .

Other variables may affect fruit $\mathrm{Ca}$ composition such as genotype and rootstock. It was observed that fruits of 'Abbè Fetel' grafted on quince 'Sydo' were more tolerant to brown spot than when grafted on seedling clone 'Fox 11', with a higher fraction of Ca pectate compared to 'Fox 11' (Table 3). 'Sydo' rootstock was led higher leaf and fruit $\mathrm{Ca}$ concentrations (Table 3) (QUARTIERI et al., 2013).

According to Tomala and Tszark (1994) cork spot (pear bitter pit) in 'Alexander Lucas' could be predicted using the following equation $\left.\mathrm{R}^{2}=0.84\right)$ :

$\mathrm{X}=5.46+1.33($ fruit $\mathrm{Mn})-0.13($ fruit $\mathrm{Ca})+$

\subsection{1 (fruit $\mathrm{Mg}$ )}

where: $\mathrm{Mn}, \mathrm{Ca}$ and $\mathrm{Mg}$ are expressed in $\mathrm{mg}\left(\mathrm{kg} \mathrm{dw}^{-1}\right)$. In the Hood river valley of Oregon, threshold for cork spot in 'D'Anjou' was found to be peel $\mathrm{N}: \mathrm{Ca}$ ratio $>6.3$ (CURTIS et al., 1990). On the other hand it was reported (SUGAR et al., 1992) that where fruiting is dense, $\mathrm{N}$ is diluted while $\mathrm{Ca}$ concentration increases, in agreement with the concept that a smaller leaf:fruit ratio must lead to a higher fruit Ca concentration (SUGAR et al., 1992). Hence, where fruits occur to be sparse, the fruit $\mathrm{N}: \mathrm{Ca}$ ratio is likely to be relatively high and the fruit to be more susceptible to defects (SUGAR et al., 1992).

In mature fruits, $\mathrm{Ca}$ concentration increases towards the core (SAURE, 2005); the peel is approximately 4 times higher in $\mathrm{Ca}$ than the pulp. At the same time, peel $\mathrm{N}$ is usually twice as high as flesh $\mathrm{N}$; as a result, the $\mathrm{N}: \mathrm{Ca}$ ratio is lower in peel $(<10)$ than in pulp $(>10)$ (GASTOL; DOMAGALASWIATKIEWICZ, 2009).

The pear trees take up $\mathrm{NH}_{4}^{+}-\mathrm{N}$ preferentially to $\mathrm{NO}_{3}^{-}-\mathrm{N}$ (MALAGUTI et al., 2001). Because $\mathrm{Ca}^{2+}$ competes with $\mathrm{NH}_{4}^{+}-\mathrm{N}$ and $\mathrm{K}^{+}$; high application of ammonium may inhibit $\mathrm{Ca}$ root uptake. This is why ammonium fertilizers should be applied at least 40 days after blooming (FAUST, 1989), and split-applied at 3 occasions such as fruit set, fruit cell enlargement and end of summer (immediately before havest or post-harvest). The application rates should be calibrated on the basis of soil mineral-N $\left(\mathrm{NO}_{3}{ }^{-}\right.$and $\left.\mathrm{NH}_{4}^{+}\right)$(TAGLIAVINI et al., 1996). The $\mathrm{N}$ can also be dissolved in fertigation water and applied at regular intervals from flower petal drop to harvest.

\section{Micronutrients}

Among micronutrients, boron $(\mathrm{B})$ is one of the most critical in pear orchards. Indeed, it is believed that pear trees have a high $\mathrm{B}$ requirement (WOJCIK; WOJCIK, 2003). Typical symptoms of B deficiency are the reduction of fruit set and yielding, as well as small, deformed, cracked and corked fruits (Table 1). Optimum fruit $\mathrm{B}$ concentration at harvest may range between 16 and $20 \mathrm{mg} \mathrm{B} \mathrm{kg}^{-1} \mathrm{dw}^{-1}$ (RAESE, 1989). An adequate $\mathrm{B}$ concentration promotes $\mathrm{Ca}$ mobility, regulates flowering and fruit set, and contributes to a stable fruit production. In Poland, foliar application of B to 'Conference' increased fruit Ca concentration 
and storability by reducing the permeability of cortex cells and the incidence of internal browning (WOJCIK; WOJCIK, 2003). Since B is mobile in the trees of the Rosacee family (BROWN et al., 1999), the most appropriate application period is the end of summer when B is stored in permanent organs and can be remobilized to the developing fruits the following spring (SANCHEZ et al., 1998).

Despite the abundance of iron $(\mathrm{Fe})$ in soils, $\mathrm{Fe}$ acquisition by fruit crops is often impaired, compromising fruit yield and quality. The occurence of $\mathrm{Fe}$ chlorosis depends on several environmental and agronomic factors (TAGLIAVINI; ROMBOLÀ, 2001) such as soil, climatic conditions, grafting, etc. Iron concentration in pear fruits is low, ranging from 20 to $35 \mathrm{mg} \mathrm{Fe} \mathrm{kg} \mathrm{dw}^{-1}$ (Table 2). In calcareous soils, Fe can be a yield-limiting factor when trees are grafted on 'quince', the most common rootstock in Italy, that has no ability to solubilize Fe from $\mathrm{Fe}(\mathrm{OH})_{3}$. To avoid yield losses, it is a common practice to fertilize pear trees grafted on 'quince' with synthetic Fe chelates and to include sustainable orchard management practices (TAGLIAVINI; ROMBOLÀ, 2001; ÁLVAREZ-FERNÁNDEZ et al., 2004) that includes grass intercropping, soil organic matter buildup, improvement of soil drainage, etc.

Manganese (Mn) concentration in pear fruits is very low ranging from 2 to $4 \mathrm{mg} \mathrm{Mn} \mathrm{kg} \mathrm{dw}{ }^{-1}$ (Table 2). The Mn deficiency can severely reduce fruit yield and shows symptoms similar to Fe chlorosis; it may occur in alcaline and calcareous soils, but also in soils with a high content of organic matter (MARSCHNER, 1995). The Mn deficiency in pear fruits is more common with 'quince' rootstocks.

Pear is considered to be a $(\mathrm{Zn})$ sensitive species (SHEAR; FAUST, 1980). At low level of soil $\mathrm{Zn}$ availability, plant growth is impaired, and fruit set and yields are limited. Under such conditions, fruits are small, deformed and sour, and ripen early. Pear responds promptly to $\mathrm{Zn}$ foliar application. Where $\mathrm{Zn}$ deficiency occurs, pre-bloom Zn sprays are successful to increase $\mathrm{Zn}$ concentration in flowers while post-bloom $\mathrm{Zn}$ sprays are effective in promoting leaf and fruit $\mathrm{Zn}$ levels. However, fruit trees require little $\mathrm{Zn}$ in addition to $\mathrm{Zn}$-based sprays to controlling diseases; in this case, $\mathrm{Zn}$ foliar sprays are not successful in improving plant growth and fruit yield and quality (WÓJCIK; POPIÑSKA, 2009).

Copper concentration in pear fruits is low, ranging from 5 to $13 \mathrm{mg} \mathrm{Cu} \mathrm{kg} \mathrm{dw}^{-1}$ (Table 2). Pear is one of the crops most subjected to $\mathrm{Cu}$ sprays for controlling diseases in low impact agricultural systems (TOSELLI et al., 2009). As a result, soil $\mathrm{Cu}$ accumulation is frequent and may lead to $\mathrm{Cu}$ toxicity symptoms. Copper uptake by roots and plant susceptibility to $\mathrm{Cu}$ toxicity depend on soil texture, $\mathrm{pH}$, hydrous oxide content, and clay mineralogy (BRUN et al., 2001; EPSTEIN; BASSEIN, 2001; MENGEL; KIRKBY, 2001; TOSELLI et al., 2008). High soil $\mathrm{Cu}$ concentration was found to reduce the photosynthetic activity of pear trees, indirectly by inhibiting the uptake of $\mathrm{Mn}$ and $\mathrm{Zn}$-. Copper toxicity is common in sandy, low $\mathrm{pH}$ soils; in loam to silt loam soils high in organic matter, the toxicity threshold exceeds $1000 \mathrm{mg} \mathrm{Cu} \mathrm{kg}^{-1}$ (TOSELLI et al., 2008).

\section{APPLE}

\section{Nitrogen}

All other factors but $\mathrm{N}$ being equal, the higher the $\mathrm{N}$ availability in the soil and the higher the $\mathrm{N}$ uptake, the higher will be the vegetative growth of apple trees. Shoot growth responds more to enhanced soil $\mathrm{N}$ availability than root growth and crop productivity. Annual $\mathrm{N}$ uptake data based on estimates of tree growth crop productivity and mineral nutrient concentration of tree organs suggest that $\mathrm{N}$ removals from soil are in the range of 60 to $75 \mathrm{~kg} \mathrm{~N}^{-1} \mathrm{yr}^{-1}$, depending on yields (TAGLIAVINI; SCANDELLARI, 2013). The N allocation to fruits for yields from 40 to $60 \mathrm{t} \mathrm{FW}$ $\mathrm{ha}^{-1}$ are often in the range 20 to $30 \mathrm{~kg} \mathrm{~N} \mathrm{ha}^{-1}$ (Table 4). From growth resumption in spring and until two weeks from full bloom, apple trees use mainly $\mathrm{N}$ derived from remobilization, while root $\mathrm{N}$ uptake becomes the main $\mathrm{N}$ source thereafter. As recently indicated in Zanotelli et al. (2014) N uptake occurs at highest rates from 37 to 81 days after full bloom then starts to decrease (Table 5). Foliar-applied $\mathrm{N}$ is absorbed rapidly with higher efficiency and therefore represents an interesting mean to supplement soil $\mathrm{N}$ supply (TOSELLI et al., 2004), especially in postharvest, when soil $\mathrm{N}$ supply often results in increase risks of $\mathrm{N}$ leaching due to autumn and winter rainfall. Apple nutrient concentration depends on cultivars and years, being often in the range of 300-400 ppm. Excessive soil $\mathrm{N}$ availability causes luxury consumption and depresses apple fruit color in redcolored varieties mainly because of increased shading caused by excessive shoot growth; it can moreover depress shoot hardening (lignification), making them more susceptible to winter frost damages. Because $\mathrm{N}$ is highly mobile in the soil, the higher is the $\mathrm{N}$ supply the higher the risks of $\mathrm{N}$ losses by leaching or by volatilization.

\section{Potassium}

In mature and highly productive apple orchards, $\mathrm{K}$ is often the nutrient absorbed at highest rates. Apple fruit, in fact, is a strong sink for $\mathrm{K}$ and 
it normally contains significant amounts of $\mathrm{K}$, with concentration ranging from 0.55 to $0.8 \mathrm{~kg} \mathrm{~K} \mathrm{Mg}^{-1}$ fruit d.w. (ZAVALLONI et al., 2001). Therefore annual $\mathrm{K}$ uptake strongly depends on fruit yields and can range from 80 to $100 \mathrm{~kg} \mathrm{~K} \mathrm{ha}^{-1}$ with yields ranging from 40 to $60 \mathrm{Mg}$ fruit (f.w) ha ${ }^{-1}$. The $\mathrm{K}$ deficient apple trees normally have leaf $\mathrm{K}$ concentration in summer less than $1 \% \mathrm{~K}$ (dw basis), show reduced leaf photosynthesis and produce fruits with less sugars. Optimum sugar to acid ratio and fruit size are often reported in soils well endowed with $\mathrm{K}$. Trees under excessive $\mathrm{K}$ supply show sometimes Ca-related disorders and have excessive fruit $\mathrm{K} / \mathrm{Ca}$ ratios. Similarly to $\mathrm{N}$, the highest rate of $\mathrm{K}$ uptake by apple trees occurs after cell division and lasts for at least 5 weeks (Table 5); K uptake rates remain relatively high until fruit harvest. Due to its high phloem mobility, $\mathrm{K}$ allocation to fruit remains relatively stable from fruit set to fruit maturity (ZAVALLONI et al., 2001).

\section{Calcium}

Main issues related with $\mathrm{Ca}$ uptake and partitioning as well as the physiological role of $\mathrm{Ca}$ in fruits have been discussed in details in the preceding section. In apple, $\mathrm{Ca}$ is involved in the development of physiological fruit disorders such as bitter pit especially in post-harvest. On the other hand, increased fruit $\mathrm{Ca}$ content by pre-harvest $\mathrm{Ca}$ spray applications reduced the infection by Gloeosporium, an internal breakdown and softening of apples. Post-harvest $\mathrm{CaCl}_{2}$ applications are also known to reduce the decay caused by Penicillium and other fungal diseases.

Total fruit $\mathrm{Ca}$ concentration is often in the range of 200-400 ppm (dw), but differs between the peel and the flesh, where it can reach much higher concentrations $(>700 \mathrm{ppm})$. Apple cultivars differ as to their susceptibility to Ca-deficiency related bitter pit, with 'Gala' and 'Golden Delicious' being less susceptible than 'Breaburn', 'Red Decilious' and 'Stayman'. Soils in the main apple districts worldwide are often well endowed with $\mathrm{Ca}$ and Ca-related disorders are the consequence of internal problems of proper fruit $\mathrm{Ca}$ allocation rather than in Ca uptake. Total Ca uptake by apple trees can be comparable N; for instance, Scandellari et al. (2010) estimated that $74 \mathrm{~kg} \mathrm{Ca} \mathrm{ha}^{-1}$ are taken up annually by 'Gala' trees, then allocated as follows: $11 \%$ in the tree framework, $4 \%$ in fruits, $60 \%$ in leaves and $25 \%$ in pruned wood.

Several susceptible apple varieties (e.g. 'Cox's Orange Pippin') accumulate most Ca within 4-6 weeks from full bloom, but $\mathrm{Ca}$ flux into fruit can continue (even at lower rates) until 120-140 days in 'Golden D.', 'Breaburn' and 'Fuji' (ZAVALLONI et al., 2001), provided that Ca partitioning to vegetative growth is not excessive. When fruits reach large sizes (e.g. in off years) the amount of fruit Ca becomes very diluted and fruits are more prone to develop bitter pit.

Pre-harvest as well as post-harvest $\mathrm{Ca}$ sprays (usually in the form of $\mathrm{CaCl}_{2}$ or $\left.\mathrm{Ca}\left(\mathrm{NO}_{3}\right)_{2}\right)$, in the range of $0.3-0.6 \% \mathrm{w}: \mathrm{v}$ ) are the most widely means for preventing bitter pit. Cuticle $\mathrm{Ca}$ uptake rate per unit of fruit surface is higher when fruits are young, and decreases thereafter (SCHÖNHERR, 2002); considering that larger fruits in a later stage of development have larger cuticular surface, both early and late sprays are effective and often included in the management pratices where susceptible varieties are grown

Thus, grapevine berries, must and wine quality are affected by the addition of nutrients, principally by $\mathrm{N}$, that regulate the synthesis of some important compounds, such as anthocyanins, which are responsible for coloring of the must and the wine. Fermenation of the must may stop in grapes with low concentration of $\mathrm{N}$ because $\mathrm{N}$ is requested in high amount by yeasts. Nitrogen excess may increase the pulp to peel ratio, diluting the concentration of anthocyanins and promoting the migration of anthocyanins from berries to the growing plant organs. Potassium is also important for wine quality contributing to adequate berry maturation, concentration of sugars, synthesis of phenols and the regulation of $\mathrm{pH}$ and acidity. In apple and pear fruit, $\mathrm{Ca}$ and $\mathrm{K}$ are important for fruit quality and storage. Potassium is the most important component of fruit, however, any excess should be avoided and an adequate $\mathrm{K}: \mathrm{Ca}$ balance should be achieved. Adequate concentration of $\mathrm{Ca}$ in the fruit prevents pre- and post-harvest fruit disorders and, at the same time, increases tolerance to pathogens. Nitrogen availability should be monitored to avoid 
excessive $\mathrm{N}$ uptake that may decrease fruit skin color and storability.

TABLE 1- Principal symptoms of deficiency and excess of nutrients in pear fruits.

\begin{tabular}{|c|c|c|c|}
\hline Nutrient & Deficiency & Excess & Source \\
\hline $\mathrm{N}$ & $\begin{array}{l}\text { low size, high firmness, early } \\
\text { maturation, lack of flavor }\end{array}$ & $\begin{array}{l}\text { Late maturation disorders (cork spot), } \\
\text { pre and post harvest decay }\end{array}$ & Sugar et al. (1992) \\
\hline $\mathrm{P}$ & $\begin{array}{l}\text { High juiceness } \\
\text { Low size and juice acidity }\end{array}$ & $\begin{array}{l}\text { Late maturation, less aroma and } \\
\text { sweetness }\end{array}$ & Faust (1989) \\
\hline $\mathrm{K}$ & Low size & Low storage suitability, cork spot & Curtis et al. (1990) \\
\hline $\mathrm{Ca}$ & $\begin{array}{l}\text { Cork spot (bitter pit), black end, } \\
\text { internal breackdown, senescent } \\
\text { breackdown, watercore, alfalfa } \\
\text { greening, high respiration, earlier } \\
\text { maturation and peel yellowing }\end{array}$ & Delay in ethylene evolution & $\begin{array}{c}\text { Curtis et al. (1990) } \\
\text { Gorini (1988) } \\
\text { Meheriuk et al. (1982) } \\
\text { Tomala e Trzak (1994) }\end{array}$ \\
\hline $\mathrm{Zn}$ & $\begin{array}{l}\text { Low size, fruits are deformed, sour, } \\
\text { early ripen }\end{array}$ & & $\begin{array}{l}\text { Wójcik and Popiñska } \\
(2009)\end{array}$ \\
\hline $\mathrm{B}$ & $\begin{array}{l}\text { Low size, deformation, cracking, } \\
\text { corking, pitting, black end, }\end{array}$ & $\begin{array}{l}\text { Early maturation, Lower storage } \\
\text { suitability }\end{array}$ & $\mid \begin{array}{l}\text { Wojcik and Wojcik } \\
(2003)\end{array}$ \\
\hline
\end{tabular}

TABLE 2- Nutrient concentration (on a d.w. basis) in pear fruit at thinning and at harvest.

\begin{tabular}{|c|c|c|c|}
\hline Nutrient & Fruit at thinning & Fruit harvest & Source \\
\hline $\mathrm{N}\left(\mathrm{g} \mathrm{kg}^{-1}\right)$ & $7.0-8.0$ & $2.0-10.0$ & $\begin{array}{l}\text { Quartieri et al. (2002) } \\
\text { Deckers et al. (2011) } \\
\text { Sanchez (2002) }\end{array}$ \\
\hline $\mathrm{P}\left(\mathrm{g} \mathrm{kg}^{-1}\right)$ & $2.0-3.0$ & $0.7-1.2$ & $\begin{array}{l}\text { Quartieri et al. (2002) } \\
\text { Sanchez (2002) }\end{array}$ \\
\hline $\mathrm{K}\left(\mathrm{g} \mathrm{kg}^{-1}\right)$ & 10.0 & $8.0-10.0$ & Quartieri et al. (2002) \\
\hline $\mathrm{Ca}\left(\mathrm{mg} \mathrm{kg}^{-1}\right)$ & $1200-1800$ & $400-1000$ & $\begin{array}{l}\text { Quartieri et al. (2002) } \\
\text { Toselli et al. (2012) } \\
\text { Wojcik and Wojcik (2003) }\end{array}$ \\
\hline $\operatorname{Mg}\left(\mathrm{mg} \mathrm{kg}^{-1}\right)$ & $700-1000$ & $350-700$ & $\begin{array}{l}\text { Quartieri et al. (2002) } \\
\text { Sanchez (2002) }\end{array}$ \\
\hline $\mathrm{Fe}\left(\mathrm{mg} \mathrm{kg}^{-1}\right)$ & $30-70$ & $20-35$ & Sanchez (2002) \\
\hline $\operatorname{Mn}\left(\mathrm{mg} \mathrm{kg}^{-1}\right)$ & 5 & $2.5-4$ & Sanchez (2002) \\
\hline $\mathrm{Cu}\left(\mathrm{mg} \mathrm{kg}^{-1}\right)$ & 8 & $5-13$ & Sanchez (2002) \\
\hline $\mathrm{Zn}\left(\mathrm{mg} \mathrm{kg}^{-1}\right)$ & $40-80$ & $25-35$ & $\begin{array}{l}\text { Mirabdulbaghi (2014) } \\
\text { Sanchez (2002) }\end{array}$ \\
\hline $\mathrm{B}\left(\mathrm{mg} \mathrm{kg}^{-1}\right)$ & $40-80$ & $20-30$ & Wojcik and Wojcik (2003) \\
\hline
\end{tabular}

Values refers to cv. Abbé Fetel, with the exception of Sanchez (2002) = cv. Bartlett; Deckers et al. (2011)=Conference. 
TABLE 3 - Effect of rootstock on concentration of total $\mathrm{Ca}$ in leaf and fruit, Ca pectate in fruit $\mathrm{K}$ and $\mathrm{Mg}$ in fruit of pear trees (cv Abbé Fetel) 70 days before harvest.

\begin{tabular}{|l|c|c|c|c|}
\hline Rootstock & $\begin{array}{c}\text { Leaf Ca } \\
(\mathbf{\%})\end{array}$ & $\begin{array}{c}\text { Fruit Ca } \\
(\mathbf{\%})\end{array}$ & $\begin{array}{c}\text { Fruit Ca Pectate } \\
\left(\mathbf{m g ~ k g}^{-1}\right)\end{array}$ & $\begin{array}{c}\text { Brown spot symptoms } \\
\left(\mathbf{m m}^{2}\right)\end{array}$ \\
\hline Sydo (C. oblonga) & 0.82 & 0.169 & 283 & 148 \\
\hline Fox 11 (P. communis) & 0.60 & 0.106 & 252 & 185 \\
\hline $\mathrm{P}>\mathrm{F}$ & 0.001 & 0.001 & 0.001 & 0.001 \\
\hline
\end{tabular}

TABLE 4- Example of uptake and partitioning of $\mathrm{N}$ in Fuji trees with fruit yields $=70 \mathrm{t} \mathrm{ha}^{-1}$.

\begin{tabular}{|l|c|c|c|}
\hline & $\begin{array}{c}\text { Yearly produced } \\
\text { biomass (t) }\end{array}$ & $\mathbf{N}(\mathbf{\%})$ & $\begin{array}{c}\text { Removed amounts of N } \\
\left(\mathbf{k g ~ h a}^{-1}\right)\end{array}$ \\
\hline Leaves & 2.3 & 0.85 & 20 \\
\hline Fruits & 70 & 0.27 & 33 \\
\hline Framawork and pruned wood & 4.1 & 0.7 & 28 \\
\hline Fine roots & 2.9 & 0.75 & 22 \\
\hline Total & & & 103 \\
\hline
\end{tabular}

TABLE 5- Biomass increase (D.W.) and nutrient influx rate into bourse shoots with one apple fruit di melo from full bloom (day 0) to harvest (Day 158). Data are per single bourse shoot and are the average of Golden del. and Nicoter (ZANOTELLI et al., 2014).

\begin{tabular}{|l|c|c|c|c|c|c|}
\hline $\begin{array}{c}\text { Period } \\
\text { (days from full } \\
\text { bloom) }\end{array}$ & $\begin{array}{c}\text { BIOMASS } \\
\text { (D.W.) } \\
\left.\text { mg day }^{-1}\right)\end{array}$ & $\begin{array}{c}\mathbf{N} \\
\left(\mathbf{m g ~ d a y}^{-1}\right)\end{array}$ & $\begin{array}{c}\mathbf{P} \\
\left.\text { (mg day }^{-1}\right)\end{array}$ & $\begin{array}{c}\mathbf{K} \\
\left.\text { (mg day }^{-1}\right)\end{array}$ & $\begin{array}{c}\text { Ca } \\
\left.\text { (mg day }^{-1}\right)\end{array}$ & $\begin{array}{c}\text { Mg } \\
\text { (mg day }^{-1} \text { ) }\end{array}$ \\
\hline $0-36$ & 90 & 1.90 & 0.19 & 1.72 & 0.63 & 0.18 \\
\hline $37-81$ & 280 & 2.45 & 0.39 & 3.63 & 1.36 & 0.28 \\
\hline $82-117$ & 320 & 1.52 & 0.22 & 2.79 & 0.58 & 0.15 \\
\hline $118-158$ & 260 & 0.88 & 0.17 & 1.63 & 0.26 & 0.07 \\
\hline
\end{tabular}

\section{REFERENCE}

ÁlVAREZ, F.A.; GARCÍA, L.P.; FIDALGO, C.; ABADÍA, J.; ABADÍA, A. Foliar fertilization to control iron chlorosis in pear (Pyrus communis L.). Plant and Soil, Dordrecht, v.263, p.5-15, 2004.

BATEMAN, D.F.; LUMSDEN, R.D. Relation between calcium content and nature of pectic substances in bean hypocotyls of different ages to susceptibility to an isolate of rhizoctonia solani. Proceedings of the American Phytopathological Society, Saint Paul, v.55, p.734-738, 1965.
BELL, S.; HENSCHKE, P.A. Implications of nitrogen nutrition for grapes, fermentation and wine. Australian Journal of Grape and Wine Research, Glen Osmond, v.11, p.242-295, 2005.

BELL, S.J.; ROBSON, A. Effect of nitrogen fertilization on growth, canopy density, and yield of Vitis vinifera L. cv. Cabernet Sauvignon. American Journal of Enology and Viticulture, Davis, v.50, p. 51-358, 1999. 
BERTRAND, A.; INGARGIOLA, M.C.; DELAS, J. Effects of nitrogen fertilization and graftiong on the composition of must and wine from Merlot grapes, particularly on the presence of ethyl carbamate. In: INTERNATIONAL SYMPOSIUM ON NITROGEN IN GRAPES AND WINE, 1991, Washington. Proceeding... Washington: The American Society for Enology and Viticulture, 1991. p.215-220.

BISSON, L.F. Influence of nitrogen on yeast and fermentation of grapes. In: INTERNATIONAL SYMPOSIUM ON NITROGEN IN GRAPES AND WINE, 1991, Washington. Proceeding... Washington: The American Society for Enology and Viticulture, 1991. p.78-89.

BOONTERM,C.W.; SILAPAPUN,A.;BOONKERD, N. Effects of nitrogen, potassium fertilizer, and clusters per vine on yield and anthocyanin content in Cabernet Sauvignon grape, Suranaree. Journal of Science and Technology, Peshawar, v.17, p.155$163,2010$.

BROWN, P.H.; HU, H.N.; ROBERTS, W.J. Occurrence of sugar alcohols determines boron toxicity symptoms of ornamental species. Journal of the American Society for Horticultural Science, Alexandria, v.124, p.347-352, 1999.

BRUN, L.A.; MAILLET, J.; INSINGER, P.; P'EPIN, M. Evaluation of copperavailability to plants in copper-contaminated vineyard soils. Environmental Pollution, Barking, v.111, p.293-302, 2001.

BRUNETTO, G.; CERETTA, C.A.; KAMINSKI, J.; MELO, G.W.B.; GIROTTO, E.; TRENTIN, E.E.; LOURENZI, C.R.; VIEIRA, R.C.B.; GATIBONI, L.C. Produção e composição química da uva em videiras submetidas à adubação nitrogenada na Serra Gaúcha do Rio Grande do Sul. Ciência Rural, Santa Maria, v.39, p.2035-2041, 2009.

BRUNETTO, G.; CERETTA, C.A.; KAMINSKI, J.; MELO, G.W.B.; LOURENZI, C.R.; FURLANETTO, V.; MORAES, A. Aplicação de nitrogênio em videiras na Campanha Gaúcha: Produtividade e características químicas do mosto da uva. Ciência Rural, Santa Maria, v.37, p.389-393, 2007.

BRUNETTO, G.; CERETTA, C.A.; MELO, G.W.B.; GIROTTO, E.; FERREIRA, P.A. Application of nitrogen sources on grapevines and effect on yield and must composition. Revista Brasileira de Fruticultura, Jaboticabal, v.35, n.4, p.1042-1051, 2013.
BRUNETTO, G.; CERETTA, C.A.; MELO, G.W.B.; KAMINSKI, J.; TRENTIN, G.; GIROTTO, E.; FERREIRA, P.A.; MIOTTO, A.; TRIVELIN, P.C.O. Contribution of nitrogen from agricultural residues of rye to Niagara Rosada grape nutrition. Scientia Horticulturae, Amsterdam, v.169, p.66-70, 2014a.

BRUNETTO, G.; MELO, G.W.B.; CERETTA, C.A.; KAMINSKI, J. Concentrazione di potassio nelle bacche e valori di $\mathrm{pH}$ e zuccheri nel mosto della cv Cabernet Sauvignon innestata su diversi portinnesti nel Sud del Brasile. Acta-Italus Hortus, Sardegna, v.3, p.636-639, 2012 b.

BRUNETTO, G.; MIOTTO, A.; CERETTA, C.A.; SCHMITT, D.E.; HEINZEN, J.; MORAES, M.P.; CANTON, L.; TIECHER, T.L.; COMIN, J.J.; GIROTTO, E. Mobility of copper and zinc fractions in fungicide-amended vineyard sandy soils. Archives of Agronomy and Soil Science, Berlin, v.60, p.609$624,2014 b$.

BRUNETTO, G.; VENTURA, M.; SCANDELLARI, F.; CERETTA, C.A.; KAMINSKI, J.; MELO, G.W.B.; TAGLIAVINI, M. Nutrients release during the decomposition of mowed perennial ryegrass and white clover and its contribution to nitrogen nutrition of grapevine. Nutrient Cycling in Agroecosystems, Dordrecht, v.90, p.299-308, 2011.

CANTARELLI, C. On the activation of alcoholic fermentation in wine making. American Journal of Enology and Viticulture, Davis, v.8, p.167-175, 1957.

CASALI, C.A.; MORTELE, D.F.; RHEINHEIMER, D.S.; BRUNETTO, G.; CORSINI, A.L.M.; KAMINSKI, J. Formas e dessorção de cobre em solos cultivados com videira na Serra Gaúcha do Rio Grande do Sul. Revista Brasileira de Ciência do Solo, Viçosa, MG, v.32, p.1479-1487, 2008. (1)

CHADHA, K.L; SHIKHAMANY, S.D. The grape improvement, production and post-harvest management. New Delhi: Malhotra Publishing House, 1999. 579p.

CHRISTENSEN, L.P.; BIANCHI, M.L.; PEACOCK, W.; HIRSCHFELT, D. Effect of nitrogen fertilizer timing and rate on inorganic nitrogen status, fruit composition, and yield of grapevines. American Journal of Enology and Viticulture, Davis, v.45, p. 376-387, 1994. 
CQFS - Comissão de Química e Fertilidade do Solo. Manual de adubação e calagem para os Estados do Rio Grande do Sul e de Santa Catarina. 10.ed. Porto Alegre: SBCS - Núcleo Regional Sul/UFRGS, 2004. 400p.

CURTIS, D.; RIGHETTI, T.L.; MIELKE, E.; FACTEAU, T. Mineral analysis from corkspotted and normal Anjou pear fruit. Journal of the American Society for Horticultural Science, Alexandria, v.115, p.969-974, 1990.

DAL BÓ, M.A. Efeito da adubação NPK na produção, qualidade da uva e nos teores foliares de nutrientes da videira. Revista Brasileira de Fruticultura, Jaboticabal, v.14, n.2, p.189-194, 1992.

DAUGHERTY, M.P.; BRIGGS, C.J.; WELTER, S.C. Bottom-up and top-down control of pear psylla (Cacopsylla pyricola): Fertilization, plant quality, and the efficacy of the predator Anthocoris nemoralis. Biological control, New York, v.43, p.257-264, 2007.

DECKERS, T.; VERJANS, W.; SCHOOFS, H.; JANSSENS, P.; ELSEN, F. Effect of irrigation and nitrogen or potassium fertigation on yield and fruit quality on Conference pear trees in Belgium. Acta Horticulturae, The Hague, v.909, p.283-293, 2011.

DELAS, J.; MOLOT, C.; SOYER, J.P. Effects of nitrogen fertilization and grafting on the yield and quality of the crop of Vitis vinifera $\mathrm{cv}$. Merlot. In: INTERNATIONAL SYMPOSIUM ON NITROGEN IN GRAPES AND WINE, 1991, Washington. Proceedings... Washington: The American Society for Enology and Viticulture, 1991. p.242-248.

DUCHÊNE, E.; SCHNEIDER, C.; GAUDILLÈRE, J.P. Effects of nitrogen nutrition timing on fruit set of grapevine cv. Grenache. Vitis, Siebeldingen, v.40, p.45-46, 2001.

EPSTEIN, L.; BASSEIN, S. Pesticide application of copper on perennial crops in California, 1993 to 1998. Journal of Environmental Quality, Madison, v.30, p.1844-1847, 2001.
FAUST, M., 1989. Physiology of temperate zone fruit trees. John Wiley and Sons, New York, 200p.,1989.

FAUST, M.; SHEAR, C.B.; SMITH, C.B. Investigations of Corking disorders of apple. I. Mineral element gradients in AYork Imperial apples. Proceedings of the American Society for Horticultural Science, Geneva, v.91, p.69-72, 1967.

FREGONI, M. Nutrizione e fertilizzazione della vite. Bologna: Edagricole, 1980. 418p.

GASTOL, M.; DOMAGALA-SWIATKIEWICZ, I. Mineral composition of Conference pears as affected by different foliar sprays. Polish Journal of Environmental Studies, Olsztyn, v.18, p.741744, 2009

GIROTTO, E.; CERETTA, C.A.; BRUNETTO, G.; MIOTTO, A.; TIECHER, T.L.; DE CONTI, L.; LOURENZI, C.R.; LORENSINI, F.; GUBIANI, P.I.; SILVA, L.S.; NICOLOSO, F.T. Copper availability assessment of $\mathrm{Cu}$-contaminated vineyard soils using black oat cultivation and chemical extractants. Environmental Monitoring and Assessment, Dordrecht, v.1, p.1-2, 2014.

GOLDSPINK, B.; GORDON, C. Response of Vitis vinifera cv. Sauvignon blanc grapevines to timed applications of nitrogen fertilizers. In: INTERNATIONAL SYMPOSIUM ON NITROGEN IN GRAPES AND WINE, 1991, Washington. Proceeding... Washington: The American Society for Enology and Viticulture, 1991. p. 255-258.

GORINI, F. Influenza delle tecniche colturali e della conservabilità sulla qualità dellepomacee. Agricoltura e Ricerca, Napoli, v.12, p.39-42, 1988

HALL, G.; BONDADA, B.R.; KELLER, M. Loss of rachis cell viability is associated with ripening disorders in grapes. Journal of Experimental Botany, Lancaster, v.62, p.1145-1153, 2011.

HUBER, D.M.; JONES, J. The role of magnesium in plant disease. Plant and Soil, Dordrecht, v.368, p.73-85. 2013 
HUBER, D.M.; THOMPSON, L.A. Nitrogen and plant disease. In: DATNOFF, L. E.; ELMER, W. H.; HUBER, D. M. (Ed.). Mineral nutrition and plant disease. Washington: The American Phytopathological Society Press, 2007. p.31-44.

KAMINSKI, J.; BRUNETTO, G.; MOTERLE, D.; RHEIHEIMER, D.S. Depleção de formas de potássio do solo afetada por cultivos sucessivos. Revista Brasileira de Ciência do Solo, Viçosa, MG, v.31, p.1003-1010, 2007.

KELLER, M.; HRAZDINA, G. Interaction of nitrogen availability during bloom and light intensity during veraison. II. Effects on anthocyanin and phenolic development during grape ripening. American Journal of Enology and Viticulture, Davis, v.49, p.341- 349, 1998.

KELLER, M.; POOL, R.M.; HENICK-KLING, T. Excessive nitrogen supply and shoot trimming can impair colour development in Pinot Noir grapes and wine. Australian Journal of Grape and Wine Research, Glen Osmond, v.5, p.45-55, 1999.

KODUR, S. Effects of juice $\mathrm{pH}$ and potassium on juice and wine quality, and regulation of potassium in grapevines through rootstocks (Vitis): a short review. Vitis, Siebeldingen, v.50, p.1-6, 2011.

LECOURIEUX, D.; RANJEVA, R.; PUGIN, A. Calcium in plant defence-signalling pathways. New Phytologist, Oxford, v.171, p.249-269. 2006.

MALAGUTI, D.; TAGLIAVINI, M.; MASIA, A.; MARANGONI, B.; GIOACCHINI, P.; VITTORI ANTISARI, L.; MILLARD, P. Dynamic of root uptake of ammonium and nitrate by pear (Pyruscommunis L.) trees after growth resumption in spring. Developments in Plant and Soil Sciences, The Hague, v.92, p.124-125, 2001.

MARCELLE, R. D. Mineral nutrition and fruit quality. Acta Horticulturae, The Hague, v.383, p.219-226, 1995.

MARSCHNER, H. Mineral nutrition of higher plants. London: Academic Press, 1995. 674p.
MARTÍN, P.; DELGADO, R.; GONZÁLEZ, M.R.; GALLEGOS, J.I.: Colour of 'Tempranillo' grapes as affected by different nitrogen and potassium fertilization rates. Acta Horticulturae, The Hague, v.652, p.153-159, 2004.

MELO, G.W.B.; BRUNETTO, G.; BASSO, A.; HEINZEN, J. Estado nutricional, produção e composição do mosto em videiras submetidas a modos de distribuição do composto orgânico. Revista Brasileira de Fruticultura, Jaboticabal, v.34, n.2, p.493-503, 2012.

MENGEL, K.; KIRKBY, E.A. Principles of plant nutrition. Netherlands: Springer, 2001. 849p.

MILLARD, P. Internal cycling of nitrogen in trees. Acta Horticulturae, The Hague, v.383, p.3-14, 1995.

MIOTTO, A.; CERETTA, C.A.; BRUNETTO, G.; NICOLOSO, F.T.; GIROTTO, E.; FARIAS, J.G.; TIECHER, T.L.; DE CONTI, L.; TRENTIN, G. Copper uptake, accumulation and physiological changes in adult grapevines in response to excess copper in soil. Plant and Soil, Dordrecht, v.374, p.593-610, 2013.

MPELASOKA, B.S.; SCHACHTMAN, D.P.; TREEBY, M.T.; THOMAS, M.R. A review of potassium nutrition in grapevines with special emphasis on berry accumulation. Australian Journal of Grape and Wine Research, Glen Osmond, v.9, p.154-168, 2003.

OUGH, C.S.; LIDER, L.A.; COOK, J.A. Rootstockscion interactions concerning winemaking. I. Juice composition changes and effects on fermentation rate with St George and 99-R rootstocks at two nitrogen fertilizer levels. American Journal of Enology and Viticulture, Davis, v.19, p.213-227, 1968.

PACHECO, C.; CALOURO, F.; MOTA, T.; GARRIDO, J.; CASTRO, R. Influência do azoto, fósforo e potássio na produção e qualidade do mosto da Vitis vinifera cv. Loureira na região dos vinhos verdes. Actas de Horticultura, The Hague, v.18, p.11-15, 1997.

POMMER, C. V. (Ed.). Uva tecnologia de produção, pós-colheita, mercado. Porto Alegre: Cinco Continentes, 2003. 778p. 
QUARTIERI M., BALDI E., TOSELLI M., CIRIANI A., COLLINA M. E BRUNELLI A. Effetto del portinnesto e del cloruro di calcio nel controllo della maculatura bruna del pero. In: Ager Innovapero. Innovazioni di processo e di prodotto per una pericoltura di qualità, 2013, Ferrara (Italy). Atti del convegno... Ferrara (Italy): Università di Ferrara, p. 17-23, 2013.

QUARTIERI, M.; MILLARD, P.; TAGLIAVINI, M. Storage and remobilization of nitrogen by pear (Pyruscommunis L.) trees as affected by timing of N supply. European Journal of Agronomy, Amsterdam, v.17, p.105-110, 2002.

RAESE, J.T. Physiological disorders and maladies of pear fruits. Horticultural Reviews, New York, v.11, p.357-411, 1989.

RAESE, J.T.; STAIFF, D.C. Effect of fertilizer, rootstocks and season on fruit quality, fruit disorders, and mineral composition of D'Anjou pears. Acta Horticulturae, The Hague, v.256, p.183-187, 1989.

RAPP, A.; VERSINI, G. Influence of nitrogen compounds in grapes on aroma compounds of wine. In: INTERNATIONAL SYMPOSIUM ON NITROGEN IN GRAPES AND WINE, 1991, Washington. Proceeding... Washington: The American Society for Enology and Viticulture, 1991. p. 156-164.

SÁNCHEZ, E. E. Nitrogen nutrition in pear orchard. Acta Horticulturae, The Hague, v.596, p.653-657, 2002.

SÁNCHEZ, E.; RIGHETTI, T.; SUGAR, D. Partitioning and recycling of fall applied boron in Comice pears. Acta Horticulturae, The Hague, v.475, p.347-354, 1998

SAURE, M.C. Calcium translocation to fleshy fruit: its mechanism and endogenous control. Scientia Horticulturae, New Yprk, v.105, p.65-89, 2005.

SCANDELARI, F.; VENTURA, M.; GIOACCHINI, P.; VITTORI ANTISARI, L.; TAGLIAVINI, M. Seasonal pattern of net nitrogen rhizodeposition from peach (Prunus persica (L.) Batsch) trees in soils with different textures. Agriculture, Ecosystems and Environment, v. 136, p. 162-168, 2010.
SCHLEGEL, T.K.E.; SCHOENHERR, J. Penetration of calcium chloride into apple fruits as affected by stage of fruit development. Acta Horticulturae, The Hague, v.594, p.527-533, 2002.

SCHMITT, D.E.; BRUNETTO, G.; GIROTTO, E.; LORENSINI, F.; MELO, G.W.B.; GATIBONI, L.C. Phosphorus fractions in the vineyard soil of the Serra Gaúcha of Rio Grande do Sul, Brazil. Revista Brasileira de Engenharia Agrícola e Ambiental, Campina Grande, v.18, p.134-140, 2014.

SCHONHERR, J. Foliar nutrition using inorganic salts: laws of cuticular penetration. Acta Horticulturae, The Hague, v.594, p.77-84, 2002.

SHEAR, C.B.; FAUST, M. Nutritional ranges in deciduous tree fruits and nuts. Horticultural Reviews, Westport, v.2, p.142-163, 1980.

SHEAR, C.B.E.; FAUST, M. Nutritional factors influencing the mineral content of apple leaves. Journal of the American Society for Horticultural Science, Alexandria, v.96, p.234-240, 1971.

SIQUEIRA, J.O.; MOREIRA, F.M.S. Microbiologia e bioquímica do solo. Lavras: UFLA/Faepe, 2001.

SKINNER, P.W.; MATTHEWS, M. Reproductive development in grape (Vitis vinifera L.) under phosphorus-limited conditions. Scientia Horticulturae, Amsterdam, v.38, p.49-60, 1989.

SMART, R. E. Canopy microclimate implications for nitrogen effects on yield and quality. In: INTERNATIONAL SYMPOSIUM ON NITROGEN IN GRAPES AND WINE, 1991, Washington. Proceeding... Washington: The American Society for Enology and Viticulture, 1991. p. 90-101. (3)

SPAYD, S.E.; NAGEL, C.W.; EDWARDS, C.G Yeast growth in Riesling juice as affected by vineyard nitrogen fertilization. American Journal of Enology and Viticulture, Davis, v.46, p.49-55, 1995.

SPAYD, S.E.; WAMPLE, R.L.; EVANS, R.G. Nitrogen fertilization of white Riesling grapes in Washington. Must and wine composition. American Journal of Enology and Viticulture, Davis, v.45, p. 34-42, 1994. 
SUGAR, D.; RIGHETTI, T.L.; SANCHEZ, E.E.; KHEMIRA, H. Management of nitrogen and calcium in pear trees for enhancement of fruit resistance to postharvest decay. HortTechnology, Alexandria, v.2, p.382-387, 1992.

TAGLIAVINI, M.; QUARTIERI, M.; MILLARD, P. Remobilised nitrogen and root uptake of nitrate for leaf growth, flowers and developing fruits of pear $(P$. communis) trees. Plant and Soil, Dordrecht, v.195, p. 137-142, 1997.

TAGLIAVINI, M.; ROMBOLÀ, A.D. Iron deficiency and chlorosis in orchard and vineyard ecosystems. European Journal of Agronomy, Amsterdam, v.15, p.71-92, 2001.

TAGLIAVINI, M.; SCANDELLARI, F. Methodologies and concepts in the study of nutrient uptake requirements and partitioning in fruit trees. Proceedings of the Seventh International Symposium on Mineral Nutrition of Fruit Crops. Acta Horticulturae, The Hague, v.984, p.47-56, 2013.

TAGLIAVINI, M.; SCUDELLARI, D.; MARANGONI, B.; TOSELLI, M. Nitrogen fertilization management in orchards to reconcile productivity and environmental aspects. Fertilizer Research, Dordrecht, v.43, p.93-102, 1996.

TAGLIAVINI, M.; ZAVALLONI, C.; ROMBOLÀ, A.D.; QUARTIERI, M.; MALAGUTI, D.; MAZZANTI, F.; MILLARD, P.; MARANGONI, B. Mineral nutrient partitioning to fruits of deciduous trees. Acta Horticulturae, The Hague, v.512, p.131$140,2000$.

TESIC, D.; KELLER, M.; HUTTON, R.J. Influence of vineyard floor management practices on grapevine vegetative growth, yield, and fruit composition. American Journal of Enology and Viticulture, Davis, v.58, p.1-11, 2007.

TOMALA, K.; TRZAK, M. Occurrence of cork spot (pit) in Alexander Lucas pears depends on fruit mineral element content. Acta Horticulturae, The Hague, v.368, p.570-577, 1994.
TOSELLI M.; THALHEIMER, M.; TAGLIAVINI, M. Leaf uptake and partitioning of urea- $\mathrm{N}$ as affected by the concentration and volume of spray solution and by the shoot leaf position in apple (Malus domestica) trees. Journal of Horticultural Science Biotecnology, Ashford, v.79, p. 97-100, 2004.

TOSELLI, M.; FLORE, J.A.; ZAVALLONI, C.; MARANGONI, B. Nitrogen partitioning in apple trees as affected by application time. Hort Technology, v. 10, p.6-11, 2000.

TOSELLI, M.; BALDI, E.; MARCOLINI, G.; MALAGUTI, D.; QUARTIERI, M.; SORRENTI, G.; MARANGONI, B. Response of potted pear trees to increasing copper concentration in sandy and clayloam soils. Journal of Plant Nutrition, New York, v.31, p.2089-2104, 2008.

TOSELLI, M.; SCHIATTI, P.; BERTACCHINI, A.; ARA, D.; QUARTIERI, M. The accumulation of copper in soils of the Italian region Emilia-Romagna. Plant, Soil and Environment, Prague, v. 55, p.7479, 2009.

TOSELLI, M.; SORRENTI, G.; QUARTIERI, M.; BALDI, E.; MARCOLINI, G.; SOLIERI, D.; MARANGONI, B.; COLLINA, M. Use of soiland foliar-applied calcium chloride to reduce pear susceptibility to brown spot (Stemphyliumvesicarium). Journal of Plant Nutrition, New York, v.12, p.18191829, 2012.

TOSELLI, M.; ZAVALLONI, C.; MARANGONI, B.; TAGLIAVINI, M.; SCUDELLARI, D.E.; ANDREINI, G. Effetto dell'epoca di concimazione azotata e dei trattamenti di calcio sulla qualità delle pere conference. Frutticoltura, Bologna, v.9, p.4548, 1998.

VAN DER ZWET, T.; KEIL, H.L. Fire blight: a bacterial disease of Rosaceous plants. USDA, Agriculture Handbook, 1979. 510p.

WALKER, R.R.; BLACKMORE, D.H. Potassium concentration and $\mathrm{pH}$ interrelationships in grape juice and wine of Chardonnay and Shiraz from a range of rootstocks in different environments. Australian Journal of Grape and Wine Research, Glen Osmond, v.18, p.183-193, 2012. 
WÓJCIK, P.; POPIÑSKA, W. Response of Lukasovka pear trees to foliar zinc sprays. Journal of Elementology, Olsztyn, v.14, p.181-188, 2009.

WOJCIK, P.; WOJCIK, M. Effects of boron fertilization on 'Conference' pear tree vigor, nutrition and fruit yield and storability. Plant and Soil, Dordrecht, v. 256, p.413-421, 2003.

ZALAMENA, J.; CASSOL, P.C.; BRUNETTO, G.; GROHSKOPF, M.A.; MAFRA, E.M.S.H. Estado nutricional, vigor e produção em videiras cultivadas com plantas de cobertura. Revista Brasileira Fruticultura, Jaboticabal, v.35, n.4, p.1190-1200, 2013.
ZANOTELLI, D.; RECHENMACHER, M.; GUERRA, W.; CASSAR, A.; TAGLIAVINI, M. Seasonal uptake rate dynamics and partitioning of mineral nutrients by bourse shoots of field-grown apple trees. European Journal of Horticultural Science, Stuttgart, v.4, p.203-211, 2014.

ZAVALLONI, C.; MARANGONI, B.; SCUDELLARI, D.; TAGLIAVINI, M. Dynamics of uptake of calcium, potassium and magnesium into apple fruit in high density planting. Acta Horticulturae, The Hague, v.564, p.113-122, 2001. 